\title{
Migrant workers in the Brazilian formal labour market
}

\section{Trabalhadores migrantes no mercado de trabalho formal brasileiro}

\section{Trabajadores migrantes en el mercado laboral formal brasileño}

Romanello, Michele ${ }^{1}$ (Florianópolis, SC, Brasil)

ORCID ID: https://orcid.org/0000-0001-6295-8749

\begin{abstract}
:
In the last decade, Brazil has been experiencing a new cycle of international migration. The migrant population living in Brazil grew by $20 \%$ approximately, according to International Organization for Migration. The objective of this paper is to analyse the insertion of foreign workers in the Brazilian formal labour market, investigating returns to schooling of migrants compared with natives and the positive or negative discrimination that can exist in the formal job market. To perform the research of this paper, the Annual Report on Social Information database is used, analysing the period from 2010 to 2017. The methodology used to calculate the rate of return on education of native and foreign workers is based on Mincer's equation. Mincer's equation is estimated econometrically, in which the dependent variable, the log of wage or labour income, is regressed in years of schooling of the person and other controls. The return to education demonstrates a positive discrimination of international formal workers in Brazil and a convergence in return rates between native and immigrants: international return rate is approximately $37 \%$ in 2010 and approximately $20 \%$ in 2017 , while native return rate remains constant during the period, approximately $15 \%$.
\end{abstract}

Keywords: education; returns; immigration; Brazil; labour

\section{Resumo:}

$\mathrm{Na}$ última década, o Brasil viveu um novo ciclo de migração internacional. A população migrante residente no Brasil cresceu cerca de $20 \%$, segundo a Organização Internacional para as Migrações. O objetivo deste artigo é analisar a inserção de trabalhadores estrangeiros no mercado de trabalho formal brasileiro, investigando os retornos à escolaridade dos migrantes em comparação com os nativos e a discriminação positiva ou negativa que pode existir no mercado formal de trabalho. Para a realização da pesquisa deste artigo, é utilizada a base de dados do Relatório Anual de Informações Sociais, que analisa o período de 2010 a 2017. A metodologia de cálculo da taxa de retorno da educação de trabalhadores nativos e estrangeiros é baseada na equação de Mincer. A equação de Mincer é estimada econometricamente, na qual a variável dependente, o log do salário ou renda do trabalho, é regredida nos anos de escolaridade da pessoa e outros controles. O retorno da educação demonstra uma discriminação positiva dos trabalhadores formais estrangeiros no Brasil e uma convergência nas taxas de retorno entre nativos e imigrantes: a taxa de retorno internacional é de aproximadamente 37\% em 2010 e cerca de $20 \%$ em 2017 , enquanto a taxa de retorno dos nativos permanece constante no período, aproximadamente $15 \%$.

Palavras-chave: educação; retornos; imigração; Brasil; trabalho

\section{Resumen:}

En la última década, Brasil ha experimentado un nuevo ciclo de migración internacional. La población migrante que reside en Brasil ha crecido de un 20\% aproximadamente, según la Organización Internacional para las Migraciones. El objetivo de este artículo es analizar la inserción de los trabajadores extranjeros en el mercado laboral formal brasileño, investigando los retornos a la educación de los migrantes en comparación con los nativos y la discriminación positiva o negativa que puede existir en el mercado laboral formal. Para realizar la investigación de esto artículo se utiliza la base de datos del Informe Anual de Información Social, que analiza el período de 2010 a 2017. La metodología para calcular la tasa de retorno de la educación de los trabajadores nativos y extranjeros se basa en la ecuación de Mincer. La ecuación de Mincer se estima econométricamente, en la cual la variable dependiente, el logaritmo de los salarios o ingresos del trabajo, se retrocede en los años de

${ }^{1}$ Professor adjunto no Departamento de Economia e Relações Internacionais da Universidade Federal de Santa Catarina (UFSC). romanello.michele@gmail.com 
Programa de Pós-graduação em Educação, Universidade Federal do Ceará

Fortaleza-CE-Brasil

escolaridad de la persona y otros controles. El retorno a la educación muestra una discriminación positiva contra los trabajadores extranjeros formales en Brasil y una convergencia en las tasas de retorno entre nativos e inmigrantes: la tasa de retorno internacional es aproximadamente del $37 \%$ en 2010 y alrededor del $20 \%$ en 2017 , mientras que la tasa de retorno de los nativos se mantiene constante en el período, aproximadamente un $15 \%$.

Palabras clave: educación; retornos; inmigración; Brasil; trabajo

\section{Introduction}

In the last decade, Brazil has been experiencing a new cycle of international migration: between 2010 and 2015, the migrant population living in Brazil grew by $20 \%$ approximately, according to International Organization for Migration (IOM, 2018).

Immigration has always been a constant throughout the country's short history, but the reasons explaining this phenomenon are different in each historical period. In the eighteenth century, for example, Latin America, as a whole, received intense migratory flows, especially from European colonists and enslaved Africans. Already in the nineteenth century, the region attracted a new migration flow originated from the political and social crises that plagued Europe. During the twentieth century, a new wave of immigrants arrived in Latin America after World War II (Patarra, 1996).

Today, globalization has had a heavy weight in people's decision to choose a destination country.

According to Martine (2005), the migrant's horizon is less restricted to the nearest city or state capital of the country of origin. Its horizon is the world - glimpsed in the movies, on television, in communication networks with relatives and friends.

Along with this greater Brazilian visibility around the planet, another factor stands out: the international economic crisis of 2008. The crisis has had two consequences: it kept unemployment rate high for some years in Europe and US, leaving these countries less attractive for migrants, and it rose the distrust of the natives against immigrants, causing tougher migration policies, which restrict foreign entry (Bogus, Fabiano, 2015).

Finally, Brazil has become a country of destiny of two south-south migratory flows: Haitians, between 2010 and 2016, escaping from their country after the catastrophic earthquake of 2010, and Venezuelans, fleeing, starting from 2017, from economic crisis in their country.

Considering these premises, the objective of this paper is to analyse the insertion of foreign workers in the Brazilian formal labour market, investigating, in 
Programa de Pós-graduação em Educação, Universidade Federal do Ceará

Fortaleza-CE-Brasil

particular, returns to school of migrants compared with natives and the possible, positive or negative, discrimination that can exist in the formal job market.

The paper is divided into six sections, including this introduction: in the second section, international and national literature review about immigration is presented; in the third section, data and methodology used are showed; in the fourth section, foreign workers are compared with native workers in terms of personal background characteristics; in the fifth section, results of returns to school of migrants compared with natives are exhibited; and finally, the last section concludes the paper.

\section{Literature review}

The literature studying international migration identifies that immigrants arriving at various host countries are not randomly selected from the populations of source countries. The human capital theory suggests that these individuals are selfselected as they respond to earnings gaps between the source country and the host country.

Besharov, Lopez and Siegel (2013) present some highlights on this discussion. The authors report on some key patterns that characterize current migratory flows. Regarding the motivations, the migration destined to the developed countries has as main factor the increase of income, being that approximately $70 \%$ of the flow refers to the economic migrant. South-south migration is also economically motivated, but to a lesser extent, only $30 \%$ of the total number of migrants.

Van Tubergen, Maas and Flap (2004) identify that the origin and destiny of the immigrant affects his or her labour market insertion. Where different groups of immigrants are analysed with similar destinations, it is observed that, after controlling for the characteristics of individuals and the place of destination, the origins of the immigrant are fundamental to determine labour market insertion. In other words, some immigrant groups are at an advantage and others at a disadvantage, depending on the group of origin, keeping everything else constant.

Migration control is widely used as a labour policy in Brazil. According to Vilela and Sampaio (2015), when analysing residence permits for foreigners in Brazil from 2005 to 2011, certain selectivity and restrictiveness are inferred, given the predominance of authorizations for professional and highly skilled men and investors from different countries, generally more developed (North American, European and 
Programa de Pós-graduação em Educação, Universidade Federal do Ceará

Fortaleza-CE-Brasil

Asian). In an aligned way, but analysing the inverse phenomenon, about the entry of undocumented, Araujo, Filartigas and Carvalho (2015) describe the hard-working conditions of Bolivian immigrants in Brazil.

Vilela (2011), in her study on Brazil, finds that, in general, international immigrants tend to benefit from the same conditions as Brazilians. The benefits are higher for Argentines, Chinese and Koreans, followed to a lesser extent by Chileans. This is as much about income as it is about class positions. Bolivians, Paraguayans, Peruvians, and Uruguayans tend to be in similar or better occupational positions than Brazilians. However, they have a disadvantage in terms of salaries.

The methodology of estimating returns to education using the Mincer equation is widely used in Brazil. For example, we can cite Loureiro, Galrão (2001), Ueda, Hoffmann (2002), Sachsida et al. (2004) and Resende,Wyllie (2006). In general, these authors report rates of return between $10 \%$ and $20 \%$, being higher in the city than in the rural environment. This range of variation for the Mincer return to education has been robust across different databases, periods and methodologies. More recently, Barbosa Filho and Pessôa (2013) calculated the return of education using the Mincer method using data from the National Household Sample Survey (PNAD) for the years 2002 to 2009. Estimates were made by controlling the fact that the worker is male, white, working in the public sector, being formal, being unionized, and having working experience. The results suggest that each year of education in Brazil is associated with an average rise in wages between $19 \%$ and $21 \%$.

However, in the literature, there is no specific study of the return to education of migrants in Brazil; this will be a novel contribution of the research at hand.

\section{Data e methodology}

To perform the research of this paper, the Annual Report on Social Information database is used, analysing the period from 2010 to 2017 . The Annual Report on Social Information (RAIS) is a socio-economic information report requested by the Brazilian Ministry of Labour and Employment to legal entities and other employers annually, consequently its database include the population of formal workers in Brazil. 
Programa de Pós-graduação em Educação, Universidade Federal do Ceará

Fortaleza-CE-Brasil

The studied population was people employed in the formal market, that is, individuals who had employment with regular employment contract and guarantees of social protection.

The following table 1 presents data about RAIS database for each in the period 2010-2017 and, therefore, the numbers of formal workers population. Moreover, the table 1 divides the total number of workers into two groups: Brazilian workers and foreign workers. According to these numbers, the foreign workers are a small part of total workers: the percentages indicate that this group represent between $0,13 \%$ and $0,31 \%$ of total formal workers in the country.

\section{Table 1 Number of formal workers}

\begin{tabular}{cccc} 
Year & Brazilian Workers & $\begin{array}{c}\text { Foreign } \\
\text { Workers }\end{array}$ & Total \\
\hline 2010 & $66.658 .501(99,87)$ & $88.801(0,13)$ & 66.747 .302 \\
2011 & $66.187 .689(99,85)$ & $95.728(0,15)$ & 66.283 .417 \\
2012 & $73.205 .403(99,83)$ & $121.082(0,17)$ & 73.326 .485 \\
2013 & $75.246 .638(99,80)$ & $153.872(0,20)$ & 75.400 .510 \\
2014 & $75.903 .873(99,73)$ & $203.406(0,27)$ & 76.107 .279 \\
2015 & $71.951 .950(99,69)$ & $223.152(0,31)$ & 72.175 .102 \\
2016 & $66.936 .250(99,69)$ & $208.348(0,31)$ & 67.144 .598 \\
2017 & $65.461 .736(99,70)$ & $194.146(0,30)$ & 65.655 .882 \\
\hline \multicolumn{4}{c}{561.552 .040} \\
Total & $(99,77)$ & $1.288 .535(0,23)$ & 562.840 .575 \\
Note: In brackets, percentage of each group on the total. & \\
Source: Own elaboration using RAIS data.
\end{tabular}

The most widely used way in the literature to measure returns on education is to estimate the impact of years of education on salary. This measure of the rate of return on education is based on the estimated coefficient for education in Mincer's regressions. An equation is estimated econometrically in which the dependent variable, the log of wage or labour income, is regressed in years of schooling of the person and other controls.

The estimation of the return of Mincer's equation is most easily understood from Equation 1 below. In it, the years of schooling affect the salaries paid. The following control variables are added to the equation: gender, race, experience, squared experience, whether he is a public or private sector worker and weekly hours worked (in appendices, Table A1 shows control variables and their characteristics).

$$
\ln w_{i}(h)=\alpha_{0}+\beta h_{i}+\sum_{l=1}^{l} \gamma_{l} \text { controls }_{l, i}+\varepsilon_{i}
$$


In this equation, $w_{i}$ is the wage of the ith worker, $h_{i}$ represents the years of schooling, $\beta$ is the return associated with the years of study, and the coefficient $\gamma_{1}$ is the impact on the wages of the controls used in the regression. It follows from equation 1 that:

$$
\frac{w(h)-w(h-1)}{w(h-1)}=\ln \frac{w(h)}{w(h-1)}=\ln w(h)-\ln w(h-1)=\beta
$$

That is, $\beta$ is the percentage gain in salary that results in an increase in education (Barbosa Filho and Pessôa, 2013).

\section{Personal Background Characteristics}

The first characteristic that can be considered is relative to gender. In this case, table 2 compares the situation of Brazilian and foreign workers according to gender. In both groups, men are more present than women in the period considered, but in the case of migrant workers is more accentuate. Moreover, considering the changes with the passing of time, female participation in formal job market is increasing in the case of Brazilian workers, while is decreasing in the case of foreign workers in the period 2010-2017. According to De Maria and Moretto (2018), what may explain the increase in male participation among foreigners is the entry of Haitians starting from 2011 - a flow mostly composed by men.

This is in line with the Brazilian literature on immigration. Vilela, Sampaio (2015), considering foreign entry permits in Brazil between 2005 and 2011, noted that almost all permits are for men, representing $90.6 \%$ of all permits in the analysed period, while women correspond to only $9.4 \%$.

Table 2. Percentage of formal workers according to gender

\begin{tabular}{ccccc} 
Year & \multicolumn{2}{c}{ Brazilian Workers } & \multicolumn{2}{c}{ Foreign Workers } \\
\hline & Male (\%) & Female (\%) & Male (\%) & Female (\%) \\
2010 & 60,15 & 39,85 & 68,36 & 31,64 \\
2011 & 59,89 & 40,11 & 68,97 & 31,03 \\
2012 & 59,01 & 40,99 & 70,34 & 29,66 \\
2013 & 58,51 & 41,49 & 72,40 & 27,60 \\
2014 & 58,00 & 42,00 & 73,89 & 26,11 \\
2015 & 57,47 & 42,53 & 73,99 & 26,01
\end{tabular}


Programa de Pós-graduação em Educação, Universidade Federal do Ceará

Fortaleza-CE-Brasil

\begin{tabular}{lllll}
\hline 2016 & 57,09 & 42,91 & 72,87 & 27,13 \\
2017 & 56,69 & 43,31 & 71,47 & 28,53 \\
\hline \multicolumn{2}{l}{ Source: Own elaboration using RAIS data. }
\end{tabular}

Moving to another characteristic, table 3 evidences the average age of formal workers distinguishing between native and foreign workers. At the beginning of our analysis, the difference between the two groups is relevant: foreign workers are approximately 9 years older than Brazilian workers. However, it can be noted that it exists a convergence between the two types of workers in the last years of analysis: on one side, Brazilian workers increased the average age by approximately 2 years, on the other side, foreign workers decreased their age by approximately 6 years.

\begin{tabular}{ccc}
\multicolumn{3}{c}{ Table 3. Average age of formal workers } \\
$\begin{array}{cc}\text { Brazilian } \\
\text { Year }\end{array}$ & $\begin{array}{c}\text { Forkers } \\
\text { Yeagn Workers }\end{array}$ \\
\hline 2010 & 34,40 & 43,78 \\
2011 & 34,39 & 42,70 \\
2012 & 34,63 & 41,15 \\
2013 & 34,84 & 39,28 \\
2014 & 35,11 & 37,67 \\
2015 & 35,73 & 37,37 \\
2016 & 36,36 & 37,68 \\
2017 & 36,69 & 37,88 \\
\hline Source: Own elaboration using RAIS data.
\end{tabular}

Convergence occurs also in the case of average monthly salary (table 4). At the beginning of this analysis, year 2010, foreign workers earned, on average, a salary nearly four times Brazilian workers salary. In 2017, the last year of this analysis, foreigners earned, on average, a double monthly salary compared with Brazilians.

Table 4. Average monthly salary in real terms (currency: Brazilian Real)

\begin{tabular}{ccc} 
Year & $\begin{array}{c}\text { Brazilian } \\
\text { Workers }\end{array}$ & Foreign Workers \\
\hline 2010 & 1422,00 & 5799,00 \\
2011 & 1452,58 & 5639,44 \\
2012 & 1503,87 & 5353,61 \\
2013 & 1553,15 & 4781,77 \\
2014 & 1574,53 & 3965,47 \\
2015 & 1557,89 & 3512,01 \\
2016 & 1596,87 & 3458,11
\end{tabular}


Programa de Pós-graduação em Educação, Universidade Federal do Ceará

Data from table 4 demonstrate a possible positive discrimination of migrant workers, which is fading as the years go by.

Besides positive discrimination, another factor that certainly affects the average salary is the level of education. Table 5 shows the percentage of Brazilian and foreign workers in each level of education. It can be noted that migrant workers are more concentrated in the higher levels of education compared with natives. $73,47 \%$ of migrant workers have completed at least secondary education against $66,33 \%$ of native workers; especially, foreigners have a percentage of graduated workers twice larger than Brazilians.

\begin{tabular}{|c|c|c|}
\hline Level of education & $\begin{array}{l}\text { Brazilian workers } \\
(\%)\end{array}$ & $\begin{array}{l}\text { Foreign } \\
\text { workers (\%) }\end{array}$ \\
\hline Illiterate & 0,40 & 0,86 \\
\hline Up to 5 years & 3,27 & 2,51 \\
\hline From 5 to 9 years & 10,37 & 7,54 \\
\hline Primary completed & 11,56 & 9,94 \\
\hline Secondary incomplete & 8,07 & 5,70 \\
\hline Secondary completed & 46,36 & 33,11 \\
\hline Tertiary incomplete & 3,82 & 3,18 \\
\hline Graduated & 15,60 & 34,25 \\
\hline $\begin{array}{l}\text { Master's degree } \\
\text { Doctorate dearee - }\end{array}$ & 0,42 & 1,52 \\
\hline $\mathrm{PhD}$ & 0,13 & 1,41 \\
\hline
\end{tabular}

Finally, the last characteristic of workers is nationality. Amongst total number of workers with active formal employment less than $1 \%$ is foreign in the period considered; of these, approximately 37\% were Latin American and Caribbean in 2010, and the participation of this group increased until 2017, when almost $59 \%$ of all foreigners came from Latin America and the Caribbean.

Table 6. First five nationalities according to number of workers and percentage on total foreign workers

\begin{tabular}{|c|c|c|c|c|c|}
\hline & 1st & 2nd & 3rd & 4th & 5th \\
\hline Nationality & Portugues & Argentiniar & Chilear & Bolivian & Jruguayan \\
\hline
\end{tabular}


Programa de Pós-graduação em Educação, Universidade Federal do Ceará

Fortaleza-CE-Brasil

\begin{tabular}{|c|c|c|c|c|c|c|}
\hline & $\begin{array}{l}\text { Number of } \\
\text { workers } \\
\%\end{array}$ & $\begin{array}{c}10.737 \\
12,09 \\
\end{array}$ & $\begin{array}{c}7.479 \\
8,42 \\
\end{array}$ & $\begin{array}{c}6.363 \\
7,17 \\
\end{array}$ & $\begin{array}{c}5.195 \\
5,85\end{array}$ & $\begin{array}{c}4.985 \\
5,61\end{array}$ \\
\hline & $\begin{array}{l}\text { Nationality } \\
\text { Number of }\end{array}$ & Portuguese & Argentinian & Others LA & Bolivian & Chilean \\
\hline 2011 & $\begin{array}{l}\text { workers } \\
\%\end{array}$ & $\begin{array}{c}11.262 \\
11,76\end{array}$ & $\begin{array}{c}8.004 \\
8,36\end{array}$ & $\begin{array}{c}7.209 \\
7,53\end{array}$ & $\begin{array}{c}6.996 \\
7,31\end{array}$ & $\begin{array}{c}6.696 \\
6,99\end{array}$ \\
\hline & $\begin{array}{l}\text { Nationality } \\
\text { Number of }\end{array}$ & Portuguese & Argentinian & Bolivian & Paraguayan & Others LA \\
\hline 2012 & $\begin{array}{l}\text { workers } \\
\%\end{array}$ & $\begin{array}{c}12.814 \\
10,58\end{array}$ & $\begin{array}{c}9.489 \\
7,84\end{array}$ & $\begin{array}{c}9.096 \\
7,51\end{array}$ & $\begin{array}{c}7.720 \\
6,38\end{array}$ & $\begin{array}{c}7.567 \\
6,25\end{array}$ \\
\hline 2013 & $\begin{array}{l}\text { Nationality } \\
\text { Number of } \\
\text { workers } \\
\% \\
\end{array}$ & $\begin{array}{c}20.742 \\
13,48 \\
\end{array}$ & $\begin{array}{c}13.989 \\
9,09 \\
\end{array}$ & $\begin{array}{c}11.313 \\
7,35 \\
\end{array}$ & $\begin{array}{c}10.651 \\
6,92 \\
\end{array}$ & $\begin{array}{c}9.812 \\
6,38 \\
\end{array}$ \\
\hline 2014 & $\begin{array}{l}\text { Nationality } \\
\text { Number of } \\
\text { workers } \\
\%\end{array}$ & $\begin{array}{c}43.832 \\
21,55\end{array}$ & $\begin{array}{c}14.637 \\
7,20\end{array}$ & $\begin{array}{c}12.860 \\
6,32 \\
\end{array}$ & $\begin{array}{c}\text { Argentinian } \\
\\
12.383 \\
6,09\end{array}$ & $\begin{array}{c}11.896 \\
5,85\end{array}$ \\
\hline 2015 & $\begin{array}{l}\text { Nationality } \\
\text { Number of } \\
\text { workers } \\
\%\end{array}$ & $\begin{array}{c}59.523 \\
26,67\end{array}$ & $\begin{array}{c}14.236 \\
6,38\end{array}$ & $\begin{array}{c}12.985 \\
5,82\end{array}$ & $\begin{array}{c}12.588 \\
5,64\end{array}$ & $\begin{array}{c}11.986 \\
5,37\end{array}$ \\
\hline 2016 & $\begin{array}{l}\text { Nationality } \\
\text { Number of } \\
\text { workers } \\
\% \\
\end{array}$ & $\begin{array}{c}55.703 \\
26,74 \\
\end{array}$ & $\begin{array}{c}12.613 \\
6,05 \\
\end{array}$ & $\begin{array}{c}12.600 \\
6,05 \\
\end{array}$ & $\begin{array}{c}11.604 \\
5,57 \\
\end{array}$ & $\begin{array}{c}10.455 \\
5,02 \\
\end{array}$ \\
\hline 2017 & $\begin{array}{l}\text { Nationality } \\
\text { Number of } \\
\text { workers } \\
\%\end{array}$ & $\begin{array}{c}51.327 \\
26,44\end{array}$ & Paraguayan & Portuguese & Argentinian & $\begin{array}{r}9.061 \\
4,67 \\
\end{array}$ \\
\hline
\end{tabular}

Source: Own elaboration using RAIS data.

These figures are confirmed by table 6 , which exhibits the first five nationality in each year according to number of workers and percentage on total foreign workers.

Data show that workers from Latin America and Caribbean countries are the largest group, followed by Portuguese workers, which in the period 2010-2012 were the nationality with the highest proportion. Starting from 2013 Haitians replaced Portuguese as the first nationality in terms of number of workers, reaching in $2016 \mathrm{a}$ peak of $26,74 \%$ of total foreign workers.

This large presence of workers from Latin America and Caribbean countries is due to the geographical and cultural proximity of these countries to Brazil, but also 
Programa de Pós-graduação em Educação, Universidade Federal do Ceará

Fortaleza-CE-Brasil

to the opportunities that Brazilian job market offers to foreigners. For example, even though the working conditions of Bolivians in São Paulo are precarious, working in Brazil allows them to survive and send money to their families in Bolivia, a similar situation in other contexts - as in the case of Rizek et al. (2010), which compares Bolivian immigrants in Sao Paulo and Buenos Aires.

\section{Results}

Table 7 exhibits the results of returns to education estimated using Mincer equation (equation 1 in section 3 ). The complete results, including estimated values of controls, can be observed in tables A2 e A3 in appendices.

\begin{tabular}{ccc}
\multicolumn{2}{c}{ Table 7. Returns to education rates (\%) } \\
Bear & $\begin{array}{c}\text { Brazilian } \\
\text { Workers }\end{array}$ & Foreign Workers \\
\hline 2010 & 15,02 & 37,67 \\
2011 & 15,18 & 38,03 \\
2012 & 14,92 & 35,11 \\
2013 & 14,89 & 29,85 \\
2014 & 14,93 & 23,78 \\
2015 & 15,61 & 21,73 \\
2016 & 15,71 & 20,92 \\
2017 & 16,15 & 20,57 \\
\hline Source: Own elaboration using RAIS data. \\
Note: returns with significance level of $1 \%$.
\end{tabular}

According to table 7 , the returns to education of Brazilian workers are constant in the period analysed. Returns to education of native workers remain in a range between approximately $14 \%$ and $16 \%$. The same situation does not appear in the case of foreigners: at the beginning of this analysis (2010) the return was $37,67 \%$, a percentage more than double compared with Brazilians; this percentage decreases each year reaching in $2017,20,57 \%$, close to Brazilian workers return.

This convergence between Brazilian and foreign workers was anticipated by table 4 , in terms of average monthly salary. In conclusion, it exists a positive discrimination in job market in favour of immigrant workers.

Analysing controls variables (tables A2 e A3 in appendices), it can be evidenced that all variables confirm the expectations in both groups of workers: age raises the individual's earnings, but at decreasing rates; men, whites and public 
Programa de Pós-graduação em Educação, Universidade Federal do Ceará

Fortaleza-CE-Brasil

servants earn more than women, black/pardos and private sector workers; more time in a job increases the individual's earnings, but at decreasing rates; weekly hours of work affect positively earnings.

However, some results can be highlighted: men have in both groups higher earnings than women, however this fact is more evident in the case of foreign workers. In the period $2010-2017$, convergence happens between native and foreign workers in terms of return to gender characteristic: in 2007 in both groups, men earn approximately $25 \%$ more than women. Convergence is positive, but the general gender pay gap is high comparing with other countries. For example, average gender pay gap in 2008 was $14,8 \%$ in OECD countries (OECD, 2008).

The variable white has higher values in the case of foreign workers; moreover, in this group, the percentage is rising over the period, passing approximately from $23 \%$ in 2010 to $32 \%$ in 2017. Probable explanations to this result are the increase of arrivals of Haitian over the period analysed and the possible discrimination of natives against these workers. Costa de Sá, Silva (2016) explain that the biggest problems faced by Haitians in Brazil are racial discrimination, the difficulty of communication with Brazilians and the economic marginalization they face, residing in peripheral areas and in some cases acting below the qualifications they bring from Haiti.

The same situation can be verified when variable public is examined: foreign public sector servants have a higher salary than Brazilian public sector servants, additionally the percentage increased over the period, roughly from $26 \%$ in 2010 to $50 \%$ in 2017.

To expand the analysis of this paper, returns to education have been calculated specifically for Haitians, which are the main subgroup inside foreign workers group from 2013 onwards (table 6). According to table 8, Haitians workers appear to stay in a situation completely different from the whole group of foreigners: in this case, returns to education are negative and, most of times, statistically insignificant along the period considered. Educational level of Haitian workers is extremely lower compared with the whole group of foreigners and with Brazilians. The percentage of Haitian workers with tertiary education is on average $1,73 \%$, while this percentage is $16,15 \%$ for Brazilian workers and $37,18 \%$ for foreign workers. This fact may be a possible explanation of negative discrimination against Haitians: being, most of times, workers 
Programa de Pós-graduação em Educação, Universidade Federal do Ceará

Fortaleza-CE-Brasil

with a low level of education, Haitians are considered generally low skilled workers even in the case of skilled individuals.

Table 8. Returns to education rates of Haitian workers (\%)

\begin{tabular}{cc} 
Year & $\begin{array}{l}\text { Returns to } \\
\text { education } \\
\text { rates }\end{array}$ \\
\hline 2010 & n. a. \\
2011 & $-0,58$ \\
2012 & $-0,48^{\star *}$ \\
2013 & 0,13 \\
2014 & $-0,10$ \\
2015 & $-0,51^{\star \star *}$ \\
2016 & $-0,17^{*}$ \\
2017 & $-0,35^{\star * *}$ \\
Source: Own elaboration using RAIS data. \\
Note: significance levels: * $10 \% ;{ }^{* \star} 5 \%$; ** $1 \%$.
\end{tabular}

Even considering all variables in the regression (table A4 in appendices), it can be noted a difference in terms of statistical significance with regression considering the whole group of foreigners. In the case of Haitian workers, the variable white and public appear, most of years, statistically insignificant: in both cases, the result is due to the low percentages of Haitian workers that are white (on average $9,15 \%$ in 2010 2017) and public servant (on average $0,17 \%$ in 2010-2017).

\section{Implications for public policy formulation}

The results of this paper demonstrate that the return of education for foreign workers is greater than for Brazilians in the formal job market. In general, foreign workers have a higher level of education and obtain higher wages than locals at the same level of education.

However, the paper considers only part of the reality of the Brazilian labour market. Due to the large number of immigrants wishing to enter the labour market, other foreign workers are subject to more precarious working conditions, especially in the case of undocumented workers, whose insertion will mostly take place in informal or illegal activities. We must emphasize that data on informality are more difficult to obtain accurately, especially in the latter case. 
Programa de Pós-graduação em Educação, Universidade Federal do Ceará

Fortaleza-CE-Brasil

However, foreign workers are concentrated not only in precarious conditions, but also in highly qualified occupations, especially in transnational corporations (Domeniconi and Baeninger, 2016). Immigrant workers most of times occupy specific niche markets (with or without good quality). This is evident even in the formal job market: on one side, high qualified workers with elevated returns to education, on the side, low qualified workers with bad returns, as the case of Haitians. To address these issues, the state needs to be more active in implementing public policies that consider the diversity and complexity of recent migratory flows to Brazil.

\section{Conclusions}

The analysis of personal background characteristics highlighted some attributes of foreign workers.

Generally, men are more present than women in the period considered, but in the case of migrant workers this fact is more accentuate. Female participation in formal job market is increasing in the case of Brazilian workers, while is decreasing in the case of foreign workers in the period.

Foreign workers are older than Brazilian workers in formal job market; however, it can be noted that it exists a convergence between the two types of workers in the last years of analysis.

Convergence occurs also in the case of average monthly salary. At the beginning of this analysis, foreign workers earned, on average, a salary nearly four times Brazilian workers salary. In the last year of this analysis, foreigners earned, on average, a double monthly salary compared with Brazilians.

Foreign formal workers have also, on average, higher levels of education compared with native workers.

According to nationality, international formal workers are predominantly from other Latin American countries, evidencing south-south migratory flows, except for large presence of Portuguese immigrants. Starting from 2013, Haitian immigrants become the largest group of foreign formal workers, reaching more than $25 \%$ of total foreign formal workers.

The return to education demonstrates a positive discrimination of international formal workers in Brazil and a convergence in return rates between native and immigrants: international return rate is approximately $37 \%$ in 2010 and 
Programa de Pós-graduação em Educação, Universidade Federal do Ceará

Fortaleza-CE-Brasil

approximately $20 \%$ in 2017 , while native return rate remains constant during the period, approximately $15 \%$.

Returns to education have been calculated specifically for Haitians, which are the main subgroup inside foreign workers group from 2013 onwards. Haitians workers appear to stay in a situation completely different from the whole group of foreigners: in this case, returns to education are negative and, most of times, statistically insignificant along the period considered.

Finally, the main restriction of this paper is related to the lack of data on informally employed workers. In this sense, this research analyses only those workers registered in the database of the Ministry of Labour and Employment. Thus, this analysis has no ability to make inferences about self-employed workers and those employed in companies with up to 10 employees - in the latter case, there is no obligation to provide data to RAIS.

\section{Appendices}

Table A1. Control variables

\begin{tabular}{|c|c|c|}
\hline Variable & Description & Observation \\
\hline age & Age of individuals in years & \\
\hline age2 & $\begin{array}{l}\text { Squared age of individuals } \\
\text { in years }\end{array}$ & \\
\hline Male & $1=$ male $; 0=$ female & \\
\hline White & $1=$ white $; 0$ = black $/$ pardo & $\begin{array}{l}\text { ' } 1 \text { ' includes East Asian } \\
\text { ' } 0 \text { ' includes Amerindian }\end{array}$ \\
\hline Experience & $\begin{array}{l}\text { Time in the actual job in } \\
\text { years }\end{array}$ & \\
\hline experience2 & $\begin{array}{l}\text { Squared time in the actual } \\
\text { job in years }\end{array}$ & \\
\hline Public & $\begin{array}{l}1=\text { public employee; } 0= \\
\text { private employee }\end{array}$ & \\
\hline Hours & Weekly hours of work & \\
\hline
\end{tabular}


Revista Labor

Programa de Pós-graduação em Educação, Universidade Federal do Ceará

Fortaleza-CE-Brasil

\section{Table A2. Results for Brazilian workers}

\begin{tabular}{lllllllll} 
Variable & $\mathbf{2 0 1 0}$ & $\mathbf{2 0 1 1}$ & $\mathbf{2 0 1 2}$ & $\mathbf{2 0 1 3}$ & $\mathbf{2 0 1 4}$ & $\mathbf{2 0 1 5}$ & $\mathbf{2 0 1 6}$ & $\mathbf{2 0 1 7}$ \\
\hline education & 0,150 & 0,152 & 0,150 & 0,149 & 0,149 & 0,156 & 0,157 & 0,161 \\
age & 0,048 & 0,049 & 0,047 & 0,048 & 0,048 & 0,049 & 0,049 & 0,048 \\
age2 & & & & - & - & - & - & \\
& $-0,001$ & $-0,001$ & $-0,001$ & 0,001 & 0,001 & 0,001 & 0,001 & $-0,001$ \\
male & 0,297 & 0,294 & 0,285 & 0,284 & 0,280 & 0,271 & 0,259 & 0,252 \\
white & 0,098 & 0,104 & 0,093 & 0,091 & 0,098 & 0,104 & 0,110 & 0,112 \\
experience & 0,004 & 0,004 & 0,004 & 0,004 & 0,004 & 0,004 & 0,003 & 0,003 \\
experience2 & & & & - & - & - & - & \\
public & $-0,001$ & $-0,001$ & $-0,001$ & 0,001 & 0,001 & 0,001 & 0,001 & 0,001 \\
hours & 0,136 & 0,134 & 0,141 & 0,136 & 0,156 & 0,165 & 0,161 & 0,162 \\
So: & 0,009 & 0,010 & 0,010 & 0,010 & 0,011 & 0,011 & 0,011 & 0,012 \\
\hline
\end{tabular}

Source: Own elaboration using RAIS data.

Note: all coefficients with significance level of $1 \%$.

Table A3. Results for foreign workers

\begin{tabular}{|c|c|c|c|c|c|c|c|c|}
\hline Variable & 2010 & 2011 & 2012 & 2013 & 2014 & 2015 & 2016 & 2017 \\
\hline education & 0,377 & 0,380 & 0,351 & 0,298 & 0,238 & 0,217 & 0,209 & 0,206 \\
\hline age & 0,079 & 0,078 & 0,079 & 0,083 & 0,078 & 0,075 & 0,074 & 0,071 \\
\hline $\mathrm{age}^{2}$ & & & & & & & & \\
\hline male & 0,457 & 0,445 & 0,427 & 0,396 & 0,352 & 0,315 & 0,284 & 0,251 \\
\hline white & 0,230 & 0,247 & 0,249 & 0,234 & 0,283 & 0,306 & 0,327 & 0,317 \\
\hline experience & 0,004 & 0,004 & 0,004 & 0,005 & 0,006 & 0,006 & 0,006 & 0,006 \\
\hline & $-0,001$ & $-0,001$ & $-0,001$ & 0,001 & 0,001 & 0,001 & 0,001 & $-0,001$ \\
\hline public & 0,261 & 0,247 & 0,275 & 0,318 & 0,416 & 0,455 & 0,457 & 0,504 \\
\hline hours & 0,031 & 0,030 & 0,028 & 0,026 & 0,022 & 0,019 & 0,018 & 0,017 \\
\hline
\end{tabular}

Source: Own elaboration using RAIS data.

Note: all coefficients with significance level of $1 \%$.

Table A4. Results for Haitian workers

\begin{tabular}{|c|c|c|c|c|c|c|c|c|}
\hline Variable & 2010 & 2011 & 2012 & 2013 & 2014 & 2015 & 2016 & 2017 \\
\hline education & n.a. & $-0,006$ & $-0,005^{\star \star}$ & 0,002 & $-0,001$ & $-0,005^{\star * *}$ & $-0,002^{*}$ & $-0,003^{* * *}$ \\
\hline age & n.a. & 0,006 & $0,012^{* * *}$ & $0,009^{* * *}$ & $0,012^{* * *}$ & $0,014^{* * *}$ & $0,012^{* * *}$ & $0,012^{* * *}$ \\
\hline age $^{2}$ & n.a. & $-0,001$ & $-0,001^{*}$ & $-0,001^{* * *}$ & $-0,001^{* * *}$ & $-0,001^{* * *}$ & $-0,001^{* * *}$ & $-0,001^{* * *}$ \\
\hline male & n.a. & $0,097^{\star *}$ & $0,196^{* * *}$ & $0,183^{\star \star *}$ & $0,166^{\star \star \star}$ & $0,148^{\star \star \star}$ & $0,125^{\star \star \star}$ & $0,108^{\star * *}$ \\
\hline white & n.a. & $-0,046^{*}$ & $0,098^{* * *}$ & 0,016 & $-0,005$ & $-0,002$ & $-0,015^{\star * *}$ & $-0,021^{* * *}$ \\
\hline $\begin{array}{l}\text { experience } \\
\text { experience }\end{array}$ & n.a. & $0,021^{\star \star *}$ & $0,004^{* *}$ & $0,009^{\star * *}$ & $0,007^{* \star *}$ & $0,007^{\star \star \star}$ & $0,003^{* * *}$ & $0,004^{* * *}$ \\
\hline & n.a. & $-0,001$ & $0,001^{* * *}$ & $-0,001$ & 0,001 & 0,001 & $0,001^{* * *}$ & $0,001^{* * *}$ \\
\hline public & n.a. & 0,048 & $-0,078$ & 0,167 & 0,143 & $-0,117^{\star * *}$ & $-0,051$ & 0,064 \\
\hline hours & n.a. & 0,006 & 0,003 & $0,013^{\star \star \star}$ & $0,014^{* * *}$ & $0,016^{\star * *}$ & $0,012^{\star \star \star}$ & $0,016^{\star * *}$ \\
\hline
\end{tabular}

Source: Own elaboration using RAIS data.

Note: significance levels: * $10 \%$; ${ }^{* *} 5 \%$; ${ }^{* *} 1 \%$. 


\section{Bibliographic References}

ARAUJO, Ana Paula Correia de; FILARTIGAS, Danilo Magno Espíndola; CARVALHO, Luciani Coimbra de. Bolivianos no Brasil: migração internacional pelo corredor fronteiriço Puertoquijarro (BO)/Corumbá (MS). Interações, v. 16, n. 1, p. 131-141, 2015. Disponível em: https://www.scielo.br/scielo.php?script=sci arttext\&pid=S151870122015000100012\&lng=en\&nrm=iso. Acesso em: 15/02/2020.

BARBOSA FILHO, Fernando de Holanda; PESSÔA, Samuel. Educação e desenvolvimento no Brasil; In: FERREIRA, Pedro et al. Desenvolvimento econômico: uma perspectiva brasileira. Rio de Janeiro: Elsevier, 2013.

BESHAROV, Douglas; LOPEZ, Mark; SIEGEL, Melissa. International conference news: trends in migration and migration policy. Journal of Policy Analysis and Management, v. 32, n. 3, p. 655-660, 2013. Disponível em: https://www.jstor.org/stable/42001554. Acesso em: 23/02/2020.

BOGUS, Lucia Maria; FABIANO, Maria Lucia. O Brasil como destino das migrações internacionais recentes: novas relações, possibilidades e desafios. Ponto e Vírgula PUC SP, n. 18, pp. 126-145, 2015. Disponível em: https://revistas.pucsp.br/index.php/pontoevirgula/article/view/29806. Acesso em: $18 / 02 / 2020$.

COSTA DE SÁ, P.R., SILVA, R. F. Desafios à inclusão dos imigrantes haitianos na sociedade brasileira. Seminar "International Migrations, Refuge and Policies", São Paulo: UNICAMP, 2016.

DE MARIA, Pier Francesco, MORETTO, Amilton José. Inserção do imigrante latinoamericano no mercado formal de trabalho brasileiro (2006-2016): características e implicações para as políticas públicas. Espacio Abierto v.27, n.3, pp. 49-73, 2018. Disponível em: http://abep.org.br/xxencontro/files/paper/111-86.pdf. Acesso em: 02/04/2020.

INTERNATIONAL ORGANIZATION FOR MIGRATION (IOM) World Migration Report, $2018 . \quad$ Disponível em: https://www.iom.int/sites/default/files/country/docs/china/r5 world migration report 2 018 en.pdf. Acesso em: 30/01/2020.

LOUREIRO, P., GALRÃO, F. Discriminação no mercado de trabalho: uma análise dos setores rural e urbano no Brasil. Economia Aplicada, v.5, n.3, pp.519-545, 2001.

MARTINE, George. A globalização inacabada: migrações internacionais e pobreza no século 21. São Paulo em Perspectiva, São Paulo, v. 19, n. 3, 2005. Disponível em: https://www.scielo.br/scielo.php?script=sci arttext\&pid=S0102-88392005000300001. Acesso em: 14/03/2020.

ORGANISATION FOR ECONOMIC CO-OPERATION AND DEVELOPMENT (OECD) OECD Employment Outlook 2008. Statistical Annex. OECD: Paris, p. 358, 2008. 
Programa de Pós-graduação em Educação, Universidade Federal do Ceará

Fortaleza-CE-Brasil

Disponível em: http://www.oecd.org/els/emp/oecdemploymentoutlook2008.htm. Acesso em: 26/02/2020.

PATARRA, Neide Lopes Migrações internacionais: herança XX, agenda XXI. São Paulo: FNUAP, 1996.

RESENDE, M., WYLLIE, R. Retornos para a educação no Brasil: evidências empíricas adicionais. Economia Aplicada, v.10, n.3, pp.349-365, 2006. Disponível em: https://www.scielo.br/scielo.php?script=sci arttext\&pid=S1413-80502006000300003. Acesso em: 18/02/2020.

RIZEK, Cibele Saliba; GEORGES, Isabel; SILVA, Carlos Freire da. Trabalho e imigração: uma comparação Brasil-Argentina. Lua Nova n.79, pp.111-142, 2010. Disponível em: https://www.scielo.br/scielo.php?pid=S0102$\underline{64452010000100006 \& s c r i p t=s c i}$ abstract\&tlng=pt. Acesso em: 26/03/2020.

SACHSIDA, A, LOUREIRO, P., MENDONÇA, M. Um estudo sobre o retorno em escolaridade no Brasil. Revista Brasileira de Economia, v.58, n.2, pp.249-265, 2004. Disponível em: https://www.scielo.br/scielo.php?pid=S0034-

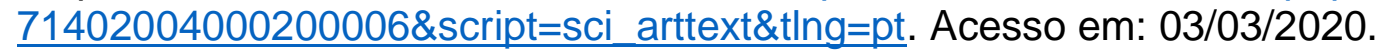

UEDA, E., HOFFMANN, R. Estimando o retorno em educação no Brasil. Economia Aplicada, v.6, n.2, pp.209-238, 2002.

VAN TUBERGEN, Frank; MAAS, Ineke; FLAP, Hen. The economic incorporation of immigrants in 18 western societies: origin, destination, and community effects. American Sociological Review [S.I.], v. 69, n. 5, pp. 704-727, 2004. Disponível em: https://www.jstor.org/stable/3593035. Acesso em: 24/01/2020.

VILELA, Elaine Meire. Desigualdade e Discriminação de Imigrantes Internacionais no Mercado de Trabalho Brasileiro. Dados - Revista de Ciências Sociais: Rio de Janeiro, v. 54, n. 1, pp. 89 - 128, 2011. Disponível em: https://core.ac.uk/download/pdf/187079262.pdf. Acesso em: 02/03/2020.

VILELA, Elaine Meire; SAMPAIO, Daniela Portela. Um olhar sobre as autorizações de permanência a estrangeiros no Brasil, entre 2005 e 2011. Revista Brasileira de Estudos de População, v. 32, n. 1, p. 25-48, 2015. Disponível em: https://www.scielo.br/scielo.php?script=sci arttext\&pid=S0102-30982015000100025. Acesso em: 03/01/2020. 


\section{Michele Romanello}

Florianópolis, Santa Cantarina, Brasil

Possui graduação em Economia pela Università Degli Studi Di Udine (Itália), mestrado em Economic Management and Policy pela University of Strathclyde (Reino Unido) e doutorado em Desenvolvimento Econômico pela Universidade Federal do Paraná (UFPR) em 2014. Foi trainee no Banco de Desenvolvimento do Conselho de Europa em Estrasburgo (França), onde trabalhou na análise dos aspectos econômicos e sociais dos projetos do Banco. Foi pesquisador no Centro Internacional de Políticas para o Crescimento Inclusivo do PNUD, onde adquiriu experiência sobre a análise de políticas públicas e projetos sociais. Atualmente é professor adjunto no Departamento de Economia e Relações Internacionais da Universidade Federal de Santa Catarina (UFSC). A principal área de atuação é Desenvolvimento Econômico, especialmente nos seguintes temas: educação, desigualdade, políticas públicas, microeconometria.

Email: romanello.michele@gmail.com

Link do Lattes: http://lattes.cnpq.br/7772210452070189

\section{Recebimento: 04/09/2020}

Aprovação: 13/04/2021

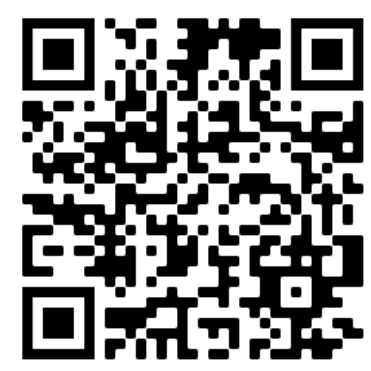

\section{Q. Code}

\section{Editores-Responsáveis}

Dr. Enéas de Araújo Arrais Neto, Universidade Federal do Ceará, UFC, Ceará, Brasil Dr. Sebastien Pesce, Universidade de Orléans, França 